\title{
Pearls \& Oy-sters: Calcified Cerebral Embolus: A Smoking Gun Guiding Acute Stroke Therapy and Secondary Prevention
}

Maria Bres Bullrich, MD, Sachin Pandey, MD, Michael Mayich, MD, Kayla McConvey, MD, Sebastian Fridman, MD, MPH, Lauren M. Mai, MD, and Luciano A. Sposato, MD, MBA

Neurology ${ }^{\circledR}$ 2021;96:e153-e156. doi:10.1212/WNL.0000000000010805

\author{
Correspondence \\ Dr. Bres Bullrich \\ mariabresbullrich@ \\ gmail.com
}

\section{Pearls}

- Although rarely found among patients with acute ischemic stroke, calcified cerebral emboli provide diagnostic information on potential stroke etiologies to guide secondary prevention.

- In the presence of a calcified cerebral embolus, all potential sources of calcific embolism should be investigated, including the aortic valve, aortic arch, and major neck vessels.

\section{Oy-sters}

- Reperfusion therapy can be challenging in patients with acute stroke and calcified cerebral emboli. IV thrombolysis has a low chance of being successful but should not be withheld. Endovascular treatment performed with a direct aspiration first-pass technique may improve the chances of a successful outcome.

A 78-year-old man presented with sudden-onset right-sided face and arm weakness and dysarthria. Upon arrival, at 60 minutes after symptoms onset, his NIH Stroke Scale (NIHSS) score was 4 (minor right facial paralysis, right arm drift, limb ataxia present in $1 \mathrm{limb}$, and mild to moderate dysarthria). His medical history was relevant for type 2 diabetes, hypertension, coronary artery bypass graft, and former smoking. Two weeks prior to the stroke, he experienced transient vertigo and disequilibrium, which were still present at the time of his admission, although with milder intensity. Medications included aspirin $81 \mathrm{mg} / \mathrm{d}$, telmisartan $80 \mathrm{mg} / \mathrm{d}$, amlodipine $10 \mathrm{mg} / \mathrm{d}$, atenolol $50 \mathrm{mg} / \mathrm{d}$, atorvastatin $10 \mathrm{mg} / \mathrm{d}$, coenzyme Q10 $100 \mathrm{mg} / \mathrm{d}$, and metformin 2,000 mg/d.

$\mathrm{CT}$ of the head showed a subtle hypodensity involving the posterior aspect of the left insular ribbon, an Alberta Stroke Program Early CT Score of 9, and a punctate hyperdensity (maximum density of 531 Hounsfield units) within the left Sylvian fissure, consistent with a calcified cerebral embolus (CCE) (figure, A). There was also a recent ( $\leq 2$ weeks) probable infarction involving the left pons. Head and supra-aortic vessels CT angiogram showed a $29 \times 9 \mathrm{~mm}$ soft and calcified (443-1,261 Hounsfield units) aortic arch atherosclerotic plaque (figure, E) and 70\% right internal carotid artery stenosis, mild left internal carotid nonstenotic plaque, and occluded left middle cerebral artery (MCA) at its mid-distal M2 portion. On multiphase arterial images, there was attenuation of the left MCA proximal to a thrombus with a calcific component, delayed washout, and a multiphase CT angiography collateral score of 3. Perfusion imaging showed a large area of potentially reversible ischemia within the posterior aspect of the left MCA territory (figure S1, available from Dryad, doi.org/10.5061/dryad.sqv9s4n1j).

We considered using IV tissue plasminogen activator (tPA) but in light of a probable subacute infarction involving the left pontine region (figure S2, available from Dryad, doi.org/10.5061/dryad. sqv9s4n1j) matching the persistent vertigo, we decided to omit IV. The right arm weakness

From the Departments of Clinical Neurological Sciences (M.B.B., K.M., S.F., L.M.M., L.A.S.) and Medical Imaging (S.P., M.M.), London Health Sciences Center, Western University; the Heart \& Brain Lab (L.A.S.), Departments of Epidemiology and Biostatistics (L.A.S.) and Anatomy and Cell Biology (L.A.S.), and the Robarts Research Institute (L.A.S.), Western University; and the Lawson Research Institute (L.A.S.), London, Canada.

Go to Neurology.org/N for full disclosures. Funding information and disclosures deemed relevant by the authors, if any, are provided at the end of the article. 

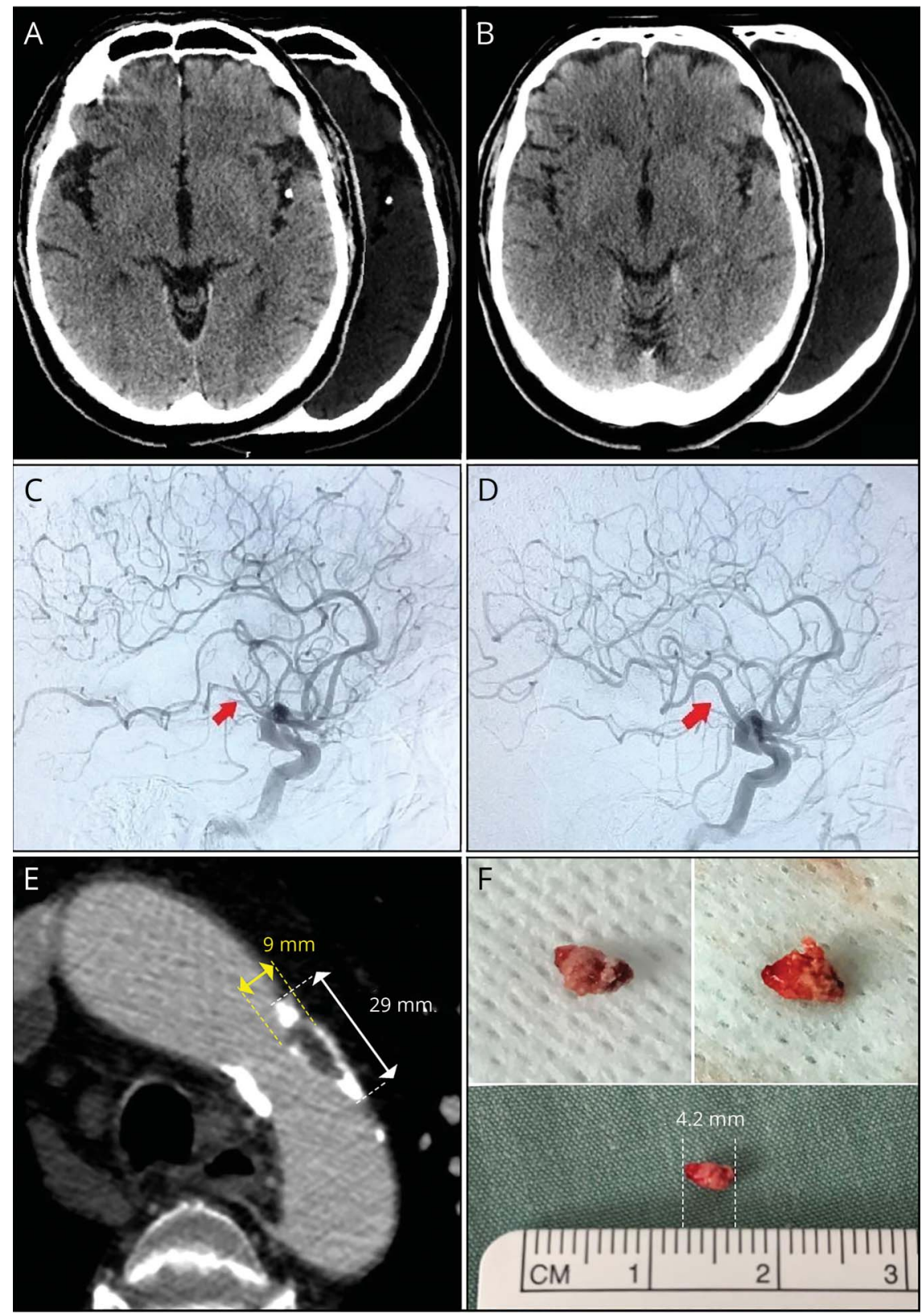

(A) Calcified cerebral embolus in the M2 segment of the left middle cerebral artery. (B) Twentyfour-hour follow-up noncontrast tomography of the head (brain and bone windows): resolution of the calcified cerebral embolus. (C) Cerebral angiogram: occlusion of the left middle cerebral artery M2 segment before mechanical thrombectomy. (D) Cerebral angiogram: resolution of the left middle cerebral artery occlusion. (E) CT angiogram of the aortic arch: aortic arch plaque measuring $9 \times 29 \mathrm{~mm}$ shows a mixed soft and calcified component. (F) Cerebral calcified embolus measuring $4.2 \mathrm{~mm}$ retrieved after 2 passes shows views of different surfaces of an irregular and sharp calcific surface. worsened after the CT angiogram was completed, resulting in NIHSS of 7. In the context of clinical worsening and a large perfusion mismatch, we decided to attempt a mechanical thrombectomy (MT) despite the lower level of evidence supporting the efficacy of the procedure in M2 occlusions compared to $\mathrm{M} 1$ or terminal internal carotid artery occlusions. ${ }^{1}$ Although a radial access was a reasonable option considering the aortic arch plaque, the team decided it was safe to pursue the MT through the right femoral artery. Time from symptoms onset to groin puncture was 2:40 hours. A diagnostic cerebral angiography confirmed an M2/M3 junction occlusion in the left MCA (figure, C). We selected a direct aspiration first pass technique (ADAPT) based on the calcific component of the thrombus.
After 2 passes with Penumbra 3Max and 6F Sofia Plus catheters, we achieved a Thrombolysis in Cerebral Infarction (TICI) score of III (figure, D) at 3:40 hours after symptoms onset.

On follow-up head CT scanning at 24 hours after MT, we confirmed the resolution of the CCE (figure, B). MRI of the brain performed 11 days after admission and almost 4 weeks after the vertiginous syndrome onset showed a small evolving infarct with mild hemorrhagic transformation in the left temporal lobe and no evidence of a pontine infarct. The electrocardiogram demonstrated sinus rhythm and a P-wave terminal force in lead $\mathrm{V} 1$ of 9,019 $\mathrm{mS}^{*} \mathrm{mV}$. The echocardiogram evidenced mild left and right atrial enlargement, with a left atrial volume index of 
$41.5 \mathrm{~mL} / \mathrm{m}^{2}$. In-hospital telemetric cardiac monitoring was unremarkable and 14-day outpatient extended electrocardiographic monitoring did not show atrial fibrillation. N-terminal pro-brain natriuretic peptide (NTpro-BNP) was $575 \mathrm{ng} / \mathrm{L}$.

The patient was discharged 48 hours after stroke onset on aspirin $81 \mathrm{mg} / \mathrm{d}$, clopidogrel $75 \mathrm{mg} / \mathrm{d}$, and atorvastatin 40 $\mathrm{mg} / \mathrm{d}$, without residual neurologic deficits, a modified Rankin Scale score of 0 , and NIHSS 0 . At 3 months he was free from recurrent vascular events.

\section{Discussion}

The key learning point of this case is the role of the CCE in guiding both hyperacute stroke treatment and secondary prevention. CCEs are uncommonly found among patients with acute ischemic stroke, with a reported frequency of up to 5.9\%. ${ }^{2}$ Most CCEs spontaneously dislodge from the aortic arch, carotid, brachiocephalic, or vertebral atherosclerotic plaques, and up to $14 \%$ of the cases result from mechanical displacement during interventional procedures. ${ }^{3}$

The finding of a CCE represents a revascularization challenge in patients with hyperacute ischemic stroke. Due to the CCE's unique structural characteristics, reports on success rates of pharmacologic and mechanical reperfusion therapy are conflicting. ${ }^{2,4,5}$ First, the calcific component is unlikely to respond to IV thrombolysis, which targets the fibrin component of the thrombus and does not affect calcium. Evidence regarding reperfusion rates with the use of IV tPA in this context is scarce and conflicting. ${ }^{4,5}$ The hard, irregular, and sharp-edged nature of CCE imposes a technical difficulty for the use of a stent retriever and has the potential to damage the vessel wall. Based on this theoretical technical limitation, we opted for a direct ADAPT, achieving TICI III reperfusion after 2 passes. In contrast to our successful procedure, attempts to retrieve a CCE using the ADAPT approach with a Penumbra catheter were unsuccessful in 5 out of 5 patients in a previous report. ${ }^{2}$

Embolic strokes of undetermined source (ESUS) are nonlacunar strokes without a cardioembolic source, occlusive atherosclerosis ( $\geq 50 \%$ luminal stenosis in arteries supplying the area of ischemia), or other specific cause. Many potential underlying causes have been identified among patients with ESUS, including aortic arch atherosclerosis, nonocclusive large artery atherosclerosis, covert paroxysmal atrial fibrillation, patent foramen ovale, cancer, and atrial cardiopathy. ${ }^{6}$ The patient presented here had an ESUS and fulfilled 3/3 criteria for atrial cardiopathy as defined in the Atrial Cardiopathy and Antithrombotic Drugs in Prevention After Cryptogenic Stroke Trial study protocol (clinicaltrials.gov/ ct2/show/NCT03192215): the presence of a P wave terminal force in $\mathrm{V} 1>5,000 \mathrm{mS}^{*} \mathrm{mV}$, left atrial enlargement, and elevated NTpro-BNP (>250 ng/L). The concept of atrial cardiopathy suggests that the mechanism causing ischemic stroke is the embolism of fibrin thrombi, usually known as red clot. The embolus retrieved in our patient had a large calcific component in coincidence with the neuroimaging findings, suggesting that atrial cardiopathy was not the cause of the stroke. The thrombus likely originated from a 9-mm mixed plaque observed in the aortic arch. ${ }^{7}$ The finding of a calcific thrombus in this patient with ESUS, atrial cardiopathy, and atherosclerotic aortic plaque has several implications. First, the presence of atrial cardiopathy may not imply a causal association with the ischemic stroke being investigated. Second, it highlights the importance of the aortic arch as a source of cerebral embolism. ${ }^{7}$ Indeed, high-risk plaque within the aortic arch has been reported in up to $8 \%^{8}$ of patients with ESUS and has been associated with over $43 \%$ risk of stroke recurrence. ${ }^{3}$ Third, investigations allowing for the assessment of the aortic arch should be part of every stroke workup, particularly in patients with clearly embolic patterns on neuroimaging studies such as cortical or multifocal infarcts. CT angiography has the advantage of being less invasive, is usually done as part of standard hyperacute stroke imaging, and is more available than transesophageal echocardiography. Fourth, given that the patient was on aspirin at the time of stroke onset, we decided to add clopidogrel. This decision was not supported by strong evidence but was rather based on the hypothesis-generating results of the Aortic Arch Related Cerebral Hazard (ARCH) trial, which was stopped prematurely in 2010 due to slow recruitment. ${ }^{9}$ This randomized controlled trial included 349 patients ( $47 \%$ of the planned 744 patients), randomized to either $75 \mathrm{mg}$ of clopidogrel $+75-150 \mathrm{mg} / \mathrm{d}$ of aspirin or warfarin. The primary efficacy endpoint was the composite of the first occurrence of ischemic stroke, myocardial infarction, peripheral embolism, vascular death, or hemorrhagic stroke. It occurred among 7.6\% (13/172) of patients in the clopidogrel + aspirin arm and in $11.3 \%(20 /$ 174 ) in the warfarin arm (unadjusted hazard ratio $0.65,95 \%$ confidence interval $0.32-1.30$ ). Among secondary outcomes, the only one showing significant differences between groups was vascular death, which was lower in the clopidogrel + aspirin group ( $0 \%$ vs $3.4 \%, p=0.013$ ). The therapeutic dilemma in this patient and the relatively high prevalence of aortic arch atheroma in the stroke population reflect the need for a randomized clinical trial assessing different antithrombotic strategies.

CCEs are easily recognized on noncontrast head CT scanning and can be useful for guiding acute stroke treatment and secondary prevention. Although there are no studies comparing ADAPT vs stent-retriever MT approaches to support either option, the former seems to be a reasonable choice in patients with CCE. Identifying competing potential ischemic stroke etiologies is common among patients with ischemic stroke and every available source of information should be considered when deciding the best secondary prevention strategy. The presence of a CCE suggests embolism from the aortic arch, calcified aortic valves, or carotid and vertebral arteries over other etiologies that are more likely to generate fibrin thrombi (e.g., atrial fibrillation, atrial cardiopathy). 


\section{Study Funding}

L.S. Sposato is supported by the Kathleen \& Dr. Henry Barnett Research Chair in Stroke Research (Western University, London, Canada); the Edward and Alma Saraydar Neurosciences Fund (London Health Sciences Foundation, Canada); and the Opportunities Fund of the Academic Health Sciences Centre Alternative Funding Plan of the Academic Medical Organization of Southwestern Ontario (AMOSO) (Canada).

\section{Disclosure}

M. Bres Bullrich, S. Pandey, M. Mayich, K. McConvey, S. Fridman, and L. Mai report no disclosures relevant to the manuscript. L. Sposato reports speaker honoraria from Boehringer Ingelheim, Pfizer, Gore, and Bayer and research/quality improvement grants from Boehringer Ingelheim and Bayer. Go to Neurology.org/ $\mathrm{N}$ for full disclosures.

Appendix Authors

\begin{tabular}{|c|c|c|}
\hline Author & Locations & Contributions \\
\hline $\begin{array}{l}\text { Maria Bres } \\
\text { Bullrich, } \\
\text { MD }\end{array}$ & $\begin{array}{l}\text { Department of Clinical } \\
\text { Neurologic Sciences, } \\
\text { London Health Sciences } \\
\text { Center, Western University }\end{array}$ & $\begin{array}{l}\text { Reviewed the case, drafted } \\
\text { the first manuscript, } \\
\text { reviewed the final version } \\
\text { of the manuscript for } \\
\text { intellectual content }\end{array}$ \\
\hline $\begin{array}{l}\text { Sachin } \\
\text { Pandey, } \\
\text { MD }\end{array}$ & $\begin{array}{l}\text { Department of Medical } \\
\text { Imaging, London Health } \\
\text { Sciences Center, Western } \\
\text { University }\end{array}$ & $\begin{array}{l}\text { Reviewed the case, edited } \\
\text { the manuscript, reviewed } \\
\text { the manuscript for } \\
\text { intellectual content }\end{array}$ \\
\hline $\begin{array}{l}\text { Michael } \\
\text { Mayich, } \\
\text { MD }\end{array}$ & $\begin{array}{l}\text { Department of Medical } \\
\text { Imaging, London Health } \\
\text { Sciences Center, Western } \\
\text { University }\end{array}$ & $\begin{array}{l}\text { Reviewed the case, edited } \\
\text { the manuscript, reviewed } \\
\text { the manuscript for } \\
\text { intellectual content }\end{array}$ \\
\hline $\begin{array}{l}\text { Kayla } \\
\text { McConvey, } \\
\text { MD }\end{array}$ & $\begin{array}{l}\text { Department of Clinical } \\
\text { Neurologic Sciences, } \\
\text { London Health Sciences } \\
\text { Center, Western University }\end{array}$ & $\begin{array}{l}\text { Reviewed the case, edited } \\
\text { the manuscript, reviewed } \\
\text { the manuscript for } \\
\text { intellectual content }\end{array}$ \\
\hline
\end{tabular}

Appendix (continued)

\begin{tabular}{|c|c|c|}
\hline Author & Locations & Contributions \\
\hline $\begin{array}{l}\text { Sebastian } \\
\text { Fridman, } \\
\text { MD, MPH }\end{array}$ & $\begin{array}{l}\text { Department of Clinical } \\
\text { Neurologic Sciences, } \\
\text { London Health Sciences } \\
\text { Center, Western University }\end{array}$ & $\begin{array}{l}\text { Reviewed the case, drafted } \\
\text { the first manuscript, } \\
\text { reviewed the final version } \\
\text { of the manuscript for } \\
\text { intellectual content }\end{array}$ \\
\hline $\begin{array}{l}\text { Lauren M. } \\
\text { Mai, MD }\end{array}$ & $\begin{array}{l}\text { Department of Clinical } \\
\text { Neurologic Sciences, } \\
\text { London Health Sciences } \\
\text { Center, Western University }\end{array}$ & $\begin{array}{l}\text { Reviewed the case, } \\
\text { drafted the first } \\
\text { manuscript, reviewed } \\
\text { the final version of } \\
\text { the manuscript } \\
\text { for intellectual } \\
\text { content }\end{array}$ \\
\hline $\begin{array}{l}\text { Luciano A. } \\
\text { Sposato, } \\
\text { MD }\end{array}$ & $\begin{array}{l}\text { Department of Clinical } \\
\text { Neurologic Sciences, } \\
\text { London Health Sciences } \\
\text { Center, Western University }\end{array}$ & $\begin{array}{l}\text { Reviewed the case, } \\
\text { drafted the first } \\
\text { manuscript, reviewed } \\
\text { the final version of } \\
\text { the manuscript } \\
\text { for intellectual } \\
\text { content }\end{array}$ \\
\hline
\end{tabular}

\section{References}

1. Powers WJ, Rabinstein AA, Ackerson T, et al. Guidelines for the early management of patients with acute ischemic stroke: 2019 update to the 2018 guidelines for the early management of acute ischemic stroke. Stroke 2019;50: e344-e418.

2. Koh E, Kwak HS, Chung GH. Manual aspiration thrombectomy in patients with acute stroke-related calcified cerebral emboli. J Stroke Cerebrovasc Dis 2017;26: 2050-2054.

3. Walker BS, Shah LM, Osborn AG. Calcified cerebral emboli, a "do not miss" imaging diagnosis: 22 new cases and review of the literature. AJNR Am J Neuroradiol 2014;35: $1515-1519$.

4. Kavanagh EC, Fenton DM, Heran MK, Lapointe JS, Nugent RA, Graeb DA. Calcified cerebral emboli. AJNR Am J Neuroradiol 2006;27:1996-1999.

5. Kissela BM, Kothari RU, Tomsick TA, Woo D, Broderick J. Embolization of calcific thrombi after tissue plasminogen activator treatment. J Stroke Cerebrovasc Dis 2001; 10:135-138.

6. Kamel H, Merkler AE, Iadecola C, Gupta A, Navi BB. Tailoring the approach to embolic stroke of undetermined source: a review. JAMA Neurol 2019;76: $855-861$.

7. Ishiyama H, Okazaki S, Saito K, Yamagami H, Ihara M. Rolling stones sign as hard and fast evidence of calcified cerebral emboli. Neurology 2018;91:41-43.

8. Ntaios G, Pearce LA, Meseguer E, et al. Aortic arch atherosclerosis in patients with embolic stroke of undetermined source: an exploratory analysis of the Navigate ESUS trial. Stroke 2019;50:3184-3190.

9. Amarenco P, Davis S, Jones EF, et al. Clopidogrel plus aspirin versus warfarin in patients with stroke and aortic arch plaques. Stroke 2014;45:1248-1257. 


\section{Neurology}

\section{Pearls \& Oy-sters: Calcified Cerebral Embolus: A Smoking Gun Guiding Acute Stroke Therapy and Secondary Prevention}

Maria Bres Bullrich, Sachin Pandey, Michael Mayich, et al.

Neurology 2021;96;e153-e156 Published Online before print September 11, 2020

DOI 10.1212/WNL.0000000000010805

This information is current as of September 11, 2020

\section{Updated Information \&} Services

References

Subspecialty Collections

Permissions \& Licensing

\section{Reprints}

including high resolution figures, can be found at: http://n.neurology.org/content/96/1/e153.full

This article cites 9 articles, 3 of which you can access for free at: http://n.neurology.org/content/96/1/e153.full\#ref-list-1

This article, along with others on similar topics, appears in the following collection(s):

\section{All Cerebrovascular disease/Stroke}

http://n.neurology.org/cgi/collection/all_cerebrovascular_disease_strok e

\section{Embolism}

http://n.neurology.org/cgi/collection/embolism

Infarction

http://n.neurology.org/cgi/collection/infarction

Stroke prevention

http://n.neurology.org/cgi/collection/stroke_prevention

Information about reproducing this article in parts (figures,tables) or in its entirety can be found online at:

http://www.neurology.org/about/about_the_journal\#permissions

Information about ordering reprints can be found online:

http://n.neurology.org/subscribers/advertise

Neurology ${ }^{\circledR}$ is the official journal of the American Academy of Neurology. Published continuously since 1951, it is now a weekly with 48 issues per year. Copyright () 2020 American Academy of Neurology. All rights reserved. Print ISSN: 0028-3878. Online ISSN: 1526-632X.

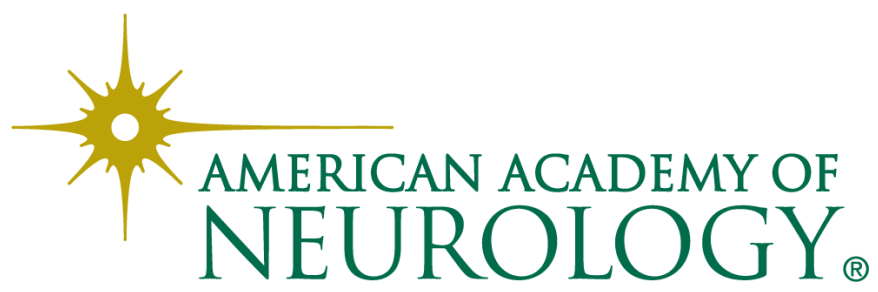

